\title{
LONG-TERM COMPLICATIONS OF DIABETES AND THE RISK OF DIABETIC FOOT
}

\section{PRZEWLEKŁE POWIKŁANIA CUKRZYCY I RYZYKO STOPY CUKRZYCOWEJ}

\author{
Iwona Krysiak-Zielonka ${ }^{1(\mathrm{~A}, \mathrm{~B}, \mathrm{C}, \mathrm{D}, \mathrm{E}, \mathrm{F}, \mathrm{G})}$ \\ ${ }^{1}$ Chair of Physiotherapy in Internal Diseases, University School of Physical Education in Wroclaw, Poland
}

Authors' contribution Wkład autorów: A. Study design/planning zaplanowanie badań B. Data collection/entry zebranie danych C. Data analysis/statistics dane - analiza i statystyki D. Data interpretation interpretacja danych E. Preparation of manuscript przygotowanie artykułu F. Literature analysis/search wyszukiwanie i analiza literatury G. Funds collection zebranie funduszy
Tables: 7

Figures: 0

References: 15

Submitted: 2016 Dec 15

Accepted: 2017 Mar 03

\section{Summary}

Background. Chronic complications of diabetes are presently the most vital problem in diabetology and the most significant challenge in the treatment of the diseases. Because of peripheral neuropathy and macroangiopathy, people with diabetes are particularly vulnerable to foot problems. The following study aims to evaluate the development of chronic complications in patients with type 2 diabetes, with a particular focus on the prevalence of limb ischemia symptoms.

Material and methods. The study involved patients with type 2 diabetes mellitus and nondiabetic persons at a similar age. Diabetics were divided into 2 groups. Group 1 consisted of type 2 diabetic patients with no trophic lesions of the limbs; Group 2 included patients with diabetic foot disease; and the control group (Group 3) were the non-diabetic elderly. The study was to analyse the incidence of retinopathy, nephropathy and neuropathy in both diabetic groups. Besides, it was to evaluate changes in macroangiopathy among diabetic patients and the control group.

Results. In all groups, symptoms of lower limb ischaemia were assessed, which allowed making comparisons between them. The studied material indicated that the occurrence of diabetic ulcers is mostly associated with macroangiopathy and its symptoms, polyneuropathy and particular types of neuropathy, retinopathy and horny foot skin.

Conclusions. An interdisciplinary approach to the problem of the diabetic foot allows recognising its early clinical symptoms.

Keywords: diabetes mellitus, chronic complications of diabetes, diabetic foot

\section{Streszczenie}

Wprowadzenie. Przewlekłe powikłania cukrzycy są obecnie najważniejszym problemem $\mathrm{w}$ diabetologii i stanowią największe wyzwanie w leczeniu cukrzycy. Z powodu obwodowej neuropatii i makroangiopatii chorzy na cukrzycę są grupą szczególnie narażoną na problemy zdrowotne stóp. Celem pracy jest ocena rozwoju przewlekłych powikłań u chorych na cukrzycę typu 2 ze szczególnym uwzględnieniem analizy częstości występowania objawów niedokrwienia kończyn.

Materiał i metody. Badaniami objęto chorych z cukrzycą typu 2 oraz osoby niechorujące na cukrzyce w podobnym przedziale wiekowym. Diabetyków podzielono na 2 grupy. Grupe 1- stanowili chorzy na cukrzycę typu 2 bez zmian troficznych kończyn, grupę 2- stanowili chorzy z zespołem stopy cukrzycowej, grupę kontrolną (grupa 3)- stanowiły osoby w wieku podeszłym niechorujące na cukrzycę. Przeanalizowano występowanie retinopatii, nefropatii i neuropatii w obu grupach diabetyków. Oceny zmian o charakterze makroangiopatii dokonano wśród chorych na cukrzycę i w grupie kontrolnej.

Wyniki. We wszystkich grupach oceniano objawy niedokrwienia kończyn dolnych. Dokonano porównań między grupami. W badanym materiale występowanie owrzodzeń cukrzycowych wiąże się $\mathrm{w}$ największym stopniu $\mathrm{z}$ makroangiopatią i jej objawami, polineuropatią $\mathrm{i}$ poszczególnymi typami neuropatii, retinopatią oraz występowaniem zrogowaciałego naskórka stóp.

Wnioski. Interdyscyplinarne podejście do problemu stopy cukrzycowej umożliwia rozpoznawanie jej wczesnych objawów klinicznych.

Słowa kluczowe: cukrzyca, przewlekłe powikłania cukrzycy, stopa cukrzycowa 


\section{Introduction}

Chronic complications of diabetes are currently the most crucial problem in diabetology and the biggest challenge in the treatment of the disease [1]. The diabetic complications are understood as a heterogeneous group of ailments and symptoms that form specific sets determining the course of the disease [2]. Severe complications are immediate life-threatening conditions, chronic, and occur in nearly all patients with longterm diabetes, which causes disability and shortens life. Major long-term complications of diabetes include the specific changes in diabetic microangiopathy, increased arteriosclerosis, as well as diabetic nephropathy and neuropathy (diabetic nephropathy).

The foot of a diabetic person is particularly susceptible to atherosclerosis and neuropathy. Microvascular microangiopathy is visible in vascular arteries and capillary blood flow disorders. These changes cause ischemia of soft tissues and bones as well as the formation of necrosis. The most important effect of peripheral neuropathy in the foot of a diabetic patient is the loss of sensation that makes the foot more sensitive and prone to minor injuries. Even a small and harmless looking interruption of the skin can become a gateway to bacteria. The development of diabetic foot infections has dangerous consequences in the form of gangrene that necessitates amputation of the affected part of the foot.

The aim of the study is to assess the development of chronic complications in patients with type 2 diabetes, with a particular focus on the prevalence_of limb ischemia symptoms.

\section{Material and methods}

The study involved patients with type 2 diabetes mellitus and non-diabetic persons at a similar age. Diabetics were divided into 2 groups. Group 1 consisted of type 2 diabetic patients with no trophic lesions (20 females, 21 males aged 40-80 years, mean age 63.8 years; duration of the disease 1-24 years, mean age 10.3 years; value of blood sugar 107-374 mg / dl; mean fasting plasma glucose level $182.1 \mathrm{mg} / \mathrm{dl}$ ). Group 2 included patients with a diabetic foot syndrome (9 females, 13 males aged 38-81 years, mean age 59.3 years); duration of illness 2-41 years, mean 19.5 years; blood sugar value $149-323 \mathrm{mg} / \mathrm{dl}$; mean fasting plasma glucose $220.1 \mathrm{mg} / \mathrm{dl}$ ). Nine ( 9 ) persons in Group 1 and 14 in Group 2 reported low glucose. Glycosuria was found in 16 persons and acetone in urine in 4 people. Further, 40 people required insulin therapy. The glycolysed hemoglobin value in both groups ranged from $5.00 \%$ to $13.26 \%$ (in Group 1, mean HBA1C was 7.16; and in Group 2 - 8.30).

Group 3 (the control group) consisted of older adults who were not diabetic (31 women, 3 men, 58-84 years, mean age 69.2 years).

Body height and BMI variables in men and women showed some differences and, as for the older people, sexual dimorphism was noticeable in height and weight.

Full research material was collected in the group of 97 persons.

Diabetic complications were assessed on the basis of surveys and specialised research. The incidence of retinopathy, nephropathy and neuropathy in both diabetic groups was analysed. Changes in macroangiopathy were evaluated both in the diabetic patients and the control group. In all groups, the following variables were analysed: the prevalence of hypertension ( $R \mathrm{R}^{3} 140$ / $90 \mathrm{mmHg}$ ); hyperlipidemia, taking $200 \mathrm{mg} / \mathrm{dL}$ as upper limit of normal value; triglyceride (TG) $200 \mathrm{mg} / \mathrm{dl}$; overweight (BMI> 25kg; obesity (BMI> $30 \mathrm{~kg} / \mathrm{m} 2$ ) and smoking. Further, in all groups, the symptoms of lower limb ischaemia were evaluated. The continuous wave Doppler (calculating the cuboidal index) was used to measure the blood pressure in the ankle region. The pulse in lower limbs was assessed palpatively, femoral arteries were examined for vascular murmur and skin was inspected for its colour and presence of superficial lesions.

Comparisons between the groups were made towards diabetic complications, macroangiopathy, the incidence of lower limb ischaemia, and atheromatous risk factors. The findings are presented in the form of the chi-square test for independence, assuming statistical significance for $\mathrm{p} £ 0,05$.

\section{Results}

The frequency of long-term complications in diabetic patients is illustrated in Table 1. 
Table 1. Prevalence of long-term complications in diabetic patients (Group 1 and Group 2)

\begin{tabular}{|c|c|c|c|c|}
\hline & \multicolumn{2}{|c|}{ Number of patients } & \multicolumn{2}{c|}{ percentage } \\
\cline { 2 - 5 } & Group 1 & Group 2 & Group 1 & Group 2 \\
\hline Retinopathy & 7 & 15 & $17 \%$ & $68 \%$ \\
\hline Nephropathy & 4 & 5 & $10 \%$ & $23 \%$ \\
\hline Neuropathy & 24 & 21 & $59 \%$ & $95 \%$ \\
\hline Polyneuropathy & 11 & 20 & $27 \%$ & $91 \%$ \\
\hline Macroangiopathy & 31 & 14 & $76 \%$ & $64 \%$ \\
\hline
\end{tabular}

A statistically significant difference was observed in the occurrence of diabetic retinopathy in diabetics. Diabetic foot syndrome (Group 2) was two-fold higher in the retinopathy group than in the non-trophic group (Group 1).

As for nephropathy, no differences were found among diabetic patients in both groups. However, the urine test for the presence of protein in Group 1 showed significant albuminuria in 14 individuals, whereas in Group 2 - in 10 persons.

Elevated serum creatinine ( $>1.1 \mathrm{mg} / \mathrm{dl}$ ) was observed in 9 persons in Group1, and 8 in Group 2 . Urea abnormalities (> 50mg / dl > 8.3mmol / l) were found in 6 persons in Group 1, and 7 in Group 2.

The percentage of people diagnosed with diabetic neuropathy was as follows: 59\% in Group 1, and 95\% in Group 2. Symmetrical polyneuropathy (sensory, motor, autonomic) was seen in $27 \%$ of the patients in Group 1, and in $91 \%$ in Group 2.

Dysfunction and deformity of the joints of the foot were found in 7\% in Group 1 and 55\% in Group 2. As for bone deformities (hamstring, clawed fingers), they were seen in $10 \%$ of the patients in Group 1, and in $27 \%$ in Group 2 .

Differences in the incidence of neuropathy in the two groups of diabetic patients were statistically significant.

The numbers and percentage of cases of major vascular disease in all groups are shown in Table 2.

Table 2. Macroangiopathy - numbers of cases in particular groups

\begin{tabular}{|c|c|c|c|c|c|c|}
\hline & \multicolumn{3}{|c|}{ Number of persons } & \multicolumn{3}{c|}{ Percentage } \\
\cline { 2 - 7 } & Group 1 & Group 2 & Group 3 & Group 1 & Group 2 & Group 3 \\
\hline Ischemic heart disease & 20 & 5 & 10 & $49 \%$ & $23 \%$ & $29 \%$ \\
\hline Ischemic stroke & 3 & 2 & 0 & $7 \%$ & $9 \%$ & $0 \%$ \\
\hline Arterial atherosclerosis & 22 & 11 & 4 & $53 \%$ & $50 \%$ & $11 \%$ \\
\hline
\end{tabular}

To illustrate the differences in the tested groups in terms of macroangiopathy, the following variables were isolated as distinct: stable and unstable angina, arrhythmia as well as myocardial infarction (Table 3). There was an increase in the number of ischemic heart disease cases in Group 1, which was close to the significance level $(p=0.07)$. There was found a significantly lower prevalence of stable angina $(p=0.001)$ in Groups 2 and 3 , but there was no significant difference in the incidence of unstable angina, arrhythmias, myocardial infarction and ischemic stroke. The high prevelance of peripheral arterial atherosclerosis in Groups 1 and 2 is a statistically significant phenomenon. (Table 3)

Table 3. Large vessel disease - a comparison between Group 1, Group 2 and Group 3

\begin{tabular}{|c|c|c|c|c|c|c|}
\hline & & Group 1 & Group 2 & Group 3 & Chi-square & p \\
\hline \multirow{2}{*}{ Ischemic heart disease } & yes & 20 & 5 & 10 & \multirow{2}{*}{5.224} & \multirow{2}{*}{0.073} \\
\hline & no & 21 & 17 & 24 & & \\
\hline \multirow{2}{*}{ Stable angina } & yes & 13 & 1 & 1 & \multirow{2}{*}{14.360} & \multirow{2}{*}{0.001} \\
\hline & no & 28 & 21 & 33 & & \\
\hline \multirow{2}{*}{ Unstable angina } & yes & 4 & 3 & 3 & \multirow{2}{*}{0.358} & \multirow{2}{*}{0.836} \\
\hline & no & 37 & 19 & 31 & & \\
\hline \multirow{2}{*}{ Irregular heart rhythm } & yes & 8 & 2 & 4 & \multirow{2}{*}{1.561} & \multirow{2}{*}{0.458} \\
\hline & no & 33 & 20 & 30 & & \\
\hline \multirow{2}{*}{ Myocardial infarction } & yes & 6 & 3 & 2 & \multirow{2}{*}{1.565} & \multirow{2}{*}{0.457} \\
\hline & no & 35 & 19 & 32 & & \\
\hline
\end{tabular}




\begin{tabular}{|c|c|c|c|c|c|c|}
\hline \multirow{2}{*}{ Stroke } & yes & 3 & 2 & 0 & \multirow{2}{*}{2.937} & \multirow{2}{*}{0.230} \\
\cline { 2 - 5 } & no & 38 & 20 & 34 & & \multirow{2}{*}{15.521} \\
\cline { 1 - 5 } $\begin{array}{c}\text { Atherosclerosis of peripheral } \\
\text { arteries }\end{array}$ & yes & 22 & 11 & 4 & $\mathbf{0 . 0 0 0 4}$ \\
\cline { 2 - 5 } & no & 19 & 11 & 30 & \\
\hline
\end{tabular}

The bold font indicates a statistical significance of $\mathrm{p} £ 0,05$ in the test; whereas the italics - the findings closest to the materiality level.

Observations of lower limb ischaemia symptoms and the comparison of their prevalence among groups are presented in Table 4.

In Group 1, 22 patients reported freezing feet and in groups 2 and 3, 17 persons in each. Intermittent claudication was diagnosed in 19 diabetics in Group 1, in 10 diabetics in Group 2, and in 3 elderly persons. No pulse on the dorsal foot and / or on the tibial posterior was reported only in patients with diabetes mellitus. Features of limb ischaemia (<0.9) showed 44\% persons in Group 1; 45\% in Group 2, and 9\% in the control group. The biggest changes in the arterial auditory examination were in Group 1: murmur over the aorta (4 persons), murmur over the right iliac (8 persons), and murmur over the left hip (6 persons). Skin lesions in the form of wounds and ulcers were predominant in the diabetic patients in Group 2.

Table 4. Prevalence of lower limb ischemia symptoms in particular groups

\begin{tabular}{|c|c|c|c|c|c|c|}
\hline & \multicolumn{3}{|c|}{ Number of persons } & \multicolumn{3}{c|}{ Percentage } \\
\cline { 2 - 7 } & Group 1 & Group 2 & Group 3 & Group 1 & Group 2 & Group 3 \\
\hline Freezing feet & 22 & 17 & 17 & $54 \%$ & $77 \%$ & $50 \%$ \\
\hline Chromatic interruptions & 19 & 10 & 3 & $46 \%$ & $45 \%$ & $9 \%$ \\
\hline Ankle brachial index (<0,9) & 18 & 10 & 3 & $44 \%$ & $45 \%$ & $9 \%$ \\
\hline Absent dorsal artery pulse & 11 & 9 & 0 & $27 \%$ & $41 \%$ & $0 \%$ \\
\hline Absent posterior tibia pulse & 8 & 8 & 0 & $20 \%$ & $36 \%$ & $0 \%$ \\
\hline Murmur over the aorta & 4 & 0 & 1 & $10 \%$ & $0 \%$ & $3 \%$ \\
\hline Murmur over the iliac artery & 14 & 1 & 6 & $34 \%$ & $5 \%$ & $18 \%$ \\
\hline Wounds, ulcers & 7 & 19 & 0 & $17 \%$ & $86 \%$ & $0 \%$ \\
\hline
\end{tabular}

A comparative analysis of the prevalence of lower limb ischemia between groups (Table 5) showed that the more frequent cases of cold feet in Group 1 could not be considered a statistically significant phenomenon. However, the low incidence of chromatic interruptions in the control group is a statistically significant phenomenon. An abnormal value of the ankle-brachial index $(<0.9)$ was significantly higher in diabetic Groups (1 and 2). Very rare pulmonary arterial hypertension in both peripheral arteries in Group 3 as well as rarely observed pulmonary arterial hypertension in Group 1 appear to be statistically significant.

Table 5. Prevalence of lower limb ischemia symptoms between groups - a comparison

\begin{tabular}{|c|c|c|c|c|c|c|}
\hline & & Group 1 & Group 2 & Group 3 & Chi-square & p \\
\hline \multirow{2}{*}{ Freezing feet } & yes & 22 & 17 & 17 & \multirow{2}{*}{4.554} & \multirow{2}{*}{0.103} \\
\hline & no & 19 & 5 & 17 & & \\
\hline \multirow{2}{*}{ Chromatic interruptions } & yes & 19 & 10 & 3 & \multirow{2}{*}{13.835} & \multirow{2}{*}{0.001} \\
\hline & no & 22 & 12 & 31 & & \\
\hline \multirow[t]{2}{*}{ Ankle brach $(<0,9)$ (R or L) } & yes & 8 & 5 & 1 & \multirow{2}{*}{5.718} & \multirow{2}{*}{0.057} \\
\hline & no & 33 & 17 & 33 & & \\
\hline \multirow{2}{*}{$\begin{array}{c}\text { Absent dorsal artery pulse } \\
(\mathrm{R} \text { or } \mathrm{L})\end{array}$} & yes & 6 & 5 & 0 & \multirow{2}{*}{7.629} & \multirow{2}{*}{0.022} \\
\hline & no & 35 & 17 & 34 & & \\
\hline \multirow{2}{*}{$\begin{array}{c}\text { Absent posterior tibia pulse } \\
\text { (R or L) }\end{array}$} & yes & 1 & 3 & 0 & \multirow{2}{*}{6.792} & \multirow{2}{*}{0.034} \\
\hline & no & 40 & 19 & 34 & & \\
\hline
\end{tabular}

The bold font indicates a statistical significance of $\mathrm{p} £ 0.05$ in the test.

$\mathrm{R}$ and $\mathrm{L}$ stand for 'right and 'left' foot

The number of people with superficial changes in feet and percentages in each group is shown in Table 6. 
Table 6. Changes in feet - symptoms in particular groups

\begin{tabular}{|c|c|c|c|c|c|c|}
\hline \multirow{2}{*}{} & \multicolumn{3}{|c|}{ Number of persons } & \multicolumn{3}{c|}{ Percentage } \\
\cline { 2 - 7 } & Group 1 & Group 2 & Group 3 & Group 1 & Group 2 & Group 3 \\
\hline Corns & 25 & 19 & 21 & $61 \%$ & $86 \%$ & $62 \%$ \\
\hline Tinea pedis & 10 & 4 & 4 & $24 \%$ & $18 \%$ & $12 \%$ \\
\hline Ingrown nails & 7 & 7 & 2 & $17 \%$ & $32 \%$ & $6 \%$ \\
\hline Thick nails & 9 & 10 & 10 & $22 \%$ & $45 \%$ & $29 \%$ \\
\hline Cracking skin & 12 & 9 & 1 & $29 \%$ & $41 \%$ & $3 \%$ \\
\hline Excessive horny epidermis & 16 & 18 & 22 & $39 \%$ & $82 \%$ & $65 \%$ \\
\hline
\end{tabular}

The most common cases of hypertrophy (86\%), cracked skin (41\%), hyperkeratosis (82\%), ingrown nails $(32 \%)$ and thick nails (45\%) were observed in patients with diabetic foot syndrome. In the group with nontrophic changes of the limbs (Group 1), the most common disorders were foot corns (61\%) and excessive keratinized epidermis (39\%).

The findings of the research showing the number of people with hypertension, hyperlipidemia, overweight, obesity and smoking tobacco are presented in Table 7.

Table 7. Selected risk factors for atherosclerosis - number and proportion of cases in groups

\begin{tabular}{|c|c|c|c|c|c|c|}
\hline \multirow{2}{*}{} & \multicolumn{3}{|c|}{ Number } & \multicolumn{3}{c|}{ Percentage } \\
\cline { 2 - 7 } & Group 1 & Group 2 & Group 3 & Group 1 & Group 2 & Group 3 \\
\hline Hypertension & 32 & 16 & 15 & $78 \%$ & $73 \%$ & $44 \%$ \\
\hline Hyperlipidemia & 23 & 10 & 20 & $56 \%$ & $45 \%$ & $59 \%$ \\
\hline Overweight & 15 & 5 & 13 & $37 \%$ & $23 \%$ & $38 \%$ \\
\hline Obesity & 21 & 9 & 0 & $51 \%$ & $41 \%$ & $0 \%$ \\
\hline Smoking & 14 & 10 & 4 & $34 \%$ & $45 \%$ & $12 \%$ \\
\hline
\end{tabular}

The diabetic group and the elderly group differed in cholesterol and triglyceride levels. In the diabetics group (Group1), significantly lower mean values of total cholesterol $(\mathrm{p}=0.006)$ was found than in the elderly group and significantly lower mean triglyceride values $(p=0.03)$. An increased number of hypertensive cases were reported in the diabetic patients without diabetes mellitus as compared to the other study groups. Also, obesity cases turned out to be more frequent than those of overweight in all patients with diabetes (Groups 1 and 2). The elderly group reported only the problem of overweight. There was a statistically significant dominance of non-smokers in the control group than in the diabetic patients.

\section{Discussion}

A statistically significant difference in the occurrence of diabetic retinopathy between the two groups of diabetics was observed in the studied material. It is confirmed by the fact that the incidence of diabetic angiopathy of the blood vessels in the eyes increases with the duration of the disease and the severity of chronic hyperglycaemia.

Differences in the incidence of neuropathy in the two groups of diabetic patients were statistically significant. And so, there was a visible dominant diabetic neuropathy foot syndrome in Group 2. An autonomic necrosis disorder results in maladaptation of the foot, which contributes to its ulceration, especially when the sensory nerve is simultaneously impaired. The motor neuropathy leads to muscle atrophy, disturbs the equilibrium of rectifiers and flexors, resulting in a limited mobility of the joints. Further, there is an impaired ability to adapt to changes, which promotes the formation of ulcers. Sensory disturbance in feeling pain, temperature, touch and disturbed sensation lower the defence mechanisms in micro-injuries, which affects the formation of ulcers. [3, 4]

The primary cause of mortality among patients with type 2 diabetes is the cardiovascular disease. [5]. By presenting an analysis of 20 non-diabetic studies, Laakso has shown that increasing glycemic levels in diabetic patients above $6.1 \mathrm{mmol} / \mathrm{l}$ are associated with an increased risk of cardiovascular disease. Similarly, basing on the results of 12 prospective studies, it has been shown that hyperglycemia has been associated with cardiovascular complications in patients with type 2 diabetes. [5] Our observations indicate that the more frequent the incidence of ischemic heart disease, the higher the incidence of ischemic heart disease. The prevalence of ischemic stroke and peripheral arterial atherosclerosis occur in people with diabetes rather than those who are not diabetic. According to Luźniak [6], except for macroangiopathy of the lower limbs, the results were similar to those on the rates of morbidity associated with particular types of macroangiopathy. In the 
material involving 1334 patients with type 2 diabetes, Luźniak et al. reported the following findings: ischemic heart disease $36 \%$, stroke 5\%, and atherosclerosis of the lower limb arteries 8\%. [6] The results from our own studies showed a significantly higher incidence of atherosclerosis in the diabetic group compared to the control group.

In the comparative analysis between the two groups on the lower limb ischemia prevalence, absence of peripheral pulse and vascular murmur on one side in diabetic patients as well as peripheral arterial calcifications were more common. It could be assumed that this group is more likely to require clinical intervention due to the tightening of the lower limb arteries.

Diabetics with co-existing Arteriosclerosis obliterans (AO) feel cold feet. They often warm them up to $40^{\circ}$ $\mathrm{C}$, which can easily be achieved by heating the skin with a hot compress. Then, blood flow should increase more than 10 times. [7] However, due to vascular disease, this condition cannot be achieved. Consequently, the skin breaks become glossy and ulcers or necrosis appear.

Some people with diabetes, despite an advanced A0, may have no intermittent claudication because they do not feel pain. This highlights the need for a periodic lower limb examination in diabetic patients for AO symptoms, even if the patient does not report them. Reducing intermittent claudication can be achieved by quitting smoking and a controlled exercise programme. [7]

Large and small vessels disease does not necessarily progress at the same rate. Often, in the case of ischemic symptoms of small vessels in toes, a pulse can be found on the dorsal artery or tibial posterior of the foot. Approximately, one third of the diabetic population may have small areas of gangrene with a perceptible pulse on the dorsal or posterior tibial artery.

Arterial insufficiency also results in other most common symptoms such as thickened toenails and fungal infection, which is also confirmed in our own studies. Besides, diabetic patients often suffer from nail distortion of their toes. Thickened clawed nails, a case of onychogryphosis, are a potential threat. When hooked on the bed linen or socks, the nails may get removed and, consequently, result in necrosis, necrotising bloody sores, ulcers and infection.

Patients may also have their nails strongly curved into the nail bed. Besides, curling nails may stick to the adjacent toes causing ulcers. Ingrown toenails are a potential source of infection, either due to ingrowing into the skin or being removed on one's own. The resulting foot infection may cause an amputation.

The analysis of risk factors for macroangiopathy in diabetic patients indicated significant values of systolic blood pressure $(\mathrm{p}=0.02)$. The mean systolic pressure was higher in Group 1 than in the diabetic group with trophic limb changes Also, when compared to the elderly group, the mean systolic pressure in Group 1 was higher. Hypertension is also diabetes-related. Patients with diabetes and coexisting high blood pressure are more likely to have increased morbidity and mortality of ischemic heart disease, stroke, or lower limb ischaemia. [6]

The diabetic group and the elderly group differed in cholesterol and triglyceride levels.

Obesity cases, rather than overweight cases, are more common in all patients with diabetes (Groups 1 and 2).

There was found a statistically significant prevalence of non-smokers in the diabetic control group.

Iwanicka et al. [8] assessed the vascular markers in patients with type 1 diabetes. The analysis included the duration of the disease and the degree of alignment. It has been shown that serum lipids are the major risk factors for macroangiopathy in children and adolescents, as they are an indicator of metabolic status.

Few prospective studies analysed the relationship between cigarette smoking and the incidence of diabetes complications. Villa, Galusa etal. [9] presented the results of a large-scale study by analysing the material collected during the period of 13 years in the USA (275,190 men and 434,637 women aged $\geq 30$ years). The findings indicate a higher incidence of diabetic foot syndrome in individuals who have smoked two or more cigarette packs per day. In male smokers, this increase amounted to $45 \%$ with regard to those who never smoked. The increase in the incidence of diabetic foot syndrome in women was $74 \%$ when compared to non-smokers. [9]

Tobacco smoking impacts many factors that can increase insulin resistance and disrupt insulin action. [10]

Both active and passive effects of cigarette smoking predispose to cardiovascular incidents. Smoking increases inflammation, thrombosis, and oxidation of low-density lipoprotein cholesterol. [11]

Obesity, and especially the distribution of adipose tissue, is also a risk factor contributing to cardiovascular disease. However, abdominal fat deposition is a higher risk for cardiovascular disease than obesity itself. Eckel, Kahn et al. have been widely analysing the relationships between obesity and type 2 diabetes. [12] The authors gather evidence to show that even a small reduction in body weight can improve glycemic control and reduce the risk of diabetes. [12]

Patients with diabetes are particularly vulnerable to foot problems due to peripheral neuropathy and macroangiopathy. Detecting high-risk patients, educating them and directing those with recognised complications to specialist centres, as well as treating comorbidities are the most critical tasks of the healthcare system. 
Persons with diabetes should be under continuous podiatry care to ensure that they are provided with professional prevention, treatment and rehabilitation that would prevent diabetic foot syndrome. Indications for referring a diabetic foot to the clinic include peripheral neuropathy, advanced limb ischemia, calluses, imprints, ingrown toenails, non-treatable ulcer, foot infection, and foot deformities.

Numerous etiologic factors contributing to the development of diabetic foot disease can be identified by simple and cost-effective equipment in the primary care (a monofilament test or vibration sensation test). Specialist counselling centres for diabetic care should also be equipped with Mini Doppler, Pedobarograph, surgical tools and specialised dressings. Careful examination, in combination with physical and subjective testing, makes it possible to identify high-risk patients and help determine the type of intervention. Effective preventive measures include patient education, good metabolic control, smoking cessation, and careful foot care. [13]

Early diagnosis of etiologic factors and dressing of ulcers is essential for a successful outcome in the prevention of diabetic foot syndrome.

Sieradzki et al., point to the results of the annual operation of the Diabetes Office in Krakow, which with the help of a multi-specialty care team showed that in the total number of patients treated, i.e. 86 , the amputation rate was only $2 \%$. $[14,15]$

\section{Conclusions}

1. The conducted examination has shown that a larger percentage of ischemic heart disease, a higher prevalence of ischemic stroke and atherosclerosis was diagnosed in patients with type 2 diabetes when compared to the general population.

2. While examining the symptoms of lower limb ischemia, more frequent abnormal values of the anklebrachial index $(<0.9)$ were observed in diabetic patients. Further, few cases of absence of pulmonary arterial pulmonary edema in patients without trophic changes in the limbs, few cases of peripheral arteries in the non diabetic group and lower incidence of intermittent claudication were found in the control group.

3. As for the predictors of macroangiopathy, there were reported: an increase in hypertension in the diabetic group with no foot symptoms and more frequent obesity cases (rather than overweight) in all diabetics. Besides, more non-smokers were found in the control group when compared with diabetic patients.

4. Diabetic ulcers are mostly associated with macroangiopathy and its manifestations; polyneuropathy and specific types of neuropathy; retinopathy as well as horny foot skin.

\section{References:}

1. Sima AAF, Bril V, Nathaniel V, McEwen TAJ, Brown MB, Lattimer SA etal. Regeneration and repair of myelinated fibers in sural-nerve biopsy specimens from patients with diabetic neuropathy treated with sorbinil. N Engl J Med, 1988,319(9): 548. https://doi.org/10.1056/NEJM198809013190905

2. Czyżyk A. Patofizjologia i klinika cukrzycy, Warszawa: PWN, 1997 (in Polish).

3. Rubins HB, Collins D, Fye CL, Anderson JW, Elam MB, Faas FH. Gemfibrozil for the secondary prevention of coronary heart disease in men with low levels of high-density lipoprotein cholesterol: Veterans Affairs HighDensity Lipoprotein Cholesterol Intervention Trial Study Group. N Engl J Med. 1999, 341: 410-418. https://doi.org/10.1056/NEJM199908053410604

4. Stess RM, Jensen SR, Mirmiran R. The role of dynamic plantar pressures in diabetic foot ulcers, Diabetes Care. 1997 May, 20(5): 855-858.

5. Laakso M. Hyperglycemia and cardiovascular disease in type 2 diabetes. Diabetes. 1999 May; 48(5): 937-942.

6. Luźniak P, Czech A, Tatoń J. Epidemiologia makroangiopatii u chorych na cukrzycę typu 2, Diabetol. Pol. 1999, 6(Suppl 1): 103 (in Polish).

7. Clark N. Peripheral Arterial Disease in People With Diabetes. Diabetes Care. 2003 Dec; 26(12): 3333-3341.

8. Iwanicka Z. Czynniki ryzyka miażdżycy u dzieci i młodzieży z cukrzycą typu 1. Diabetol. Pol. 1999, 6(Suppl 1): 68 (in Polish).

9. Will JC, Galuska DA, Ford ES, Mokdad A, Calle EE. Cigarette smoking and diabetes mellitus: evidence of a positive association from a large prospective cohort study. Int J Epidemiol, 2001, 30(3): 540-546.

10. Haire-Joshu D, Russell E, Glasgow TLT. Palenie tytoniu a cukrzyca. Diabetologia Praktyczna 2001, 2, 2: 99-115.

11. Ambrose JA, Barua RS. The pathophysiology of cigarette smoking and cardiovascular disease: An update. J Am Coll Cardiol 2004, May, 43 (10): 1731-1737. https://doi.org/10.1016/j.jacc.2003.12.047 
12. Eckel RH, Kahn SE, Ferrannini E, Goldfine AB, Nathan DM, Schwartz MW et al. Obesity and Type 2 Diabetes: What Can Be Unified and What Needs to Be Individualized? Diabetes Care. 2011 Jun, 34(6): 1424-1430. https://doi.org/10.1210/jc.2011-0585

13. Wu SC, Driver VR, Wrobel JS, Armstrong DG. Foot ulcers in the diabetic patient, prevention and treatment. Vasc Health Risk Manag. 2007 Feb. 3(1): 65-76.

14. Sieradzki J, Koblik T, Otfinowski J, Friedlein J, Legutko J, Stoch A et al. Zespół stopy cukrzycowej w praktyce klinicznej II. Wyniki rocznej działalności Gabinetu Stopy Cukrzycowej. Przegląd Lekarski 1996,53,1: 6-8 (in Polish).

15. Sieradzki J, Koblik T, Otfinowski J, Friedlein J, Legutko J, Stoch A et al. Zespół stopy cukrzycowej w praktyce klinicznej I. Model Gabinetu Stopy Cukrzycowej. Przegląd Lekarski. 1996,53,1: 3-5 (in Polish). 